\title{
Note on Transliteration, Spelling of Names, and Dates
}

A significantly modified (and we hope reader-friendly) version of the Library of Congress system for transliterating the Russian alphabet is used throughout the editor's general introduction, the editor's introductions to individual authors and their works, the English translations of works, and the notes to them. Exceptions are Russian words and geographical and personal names that have gained a common spelling in English, such as Maxim Gorky instead of "Maksim Gorky," Joseph Brodsky instead of "Iosif Brodsky," Osip Mandelstam instead of "Osip Mandelshtam," Vladimir Jabotinsky instead of "Vladimir Zhabotinsky," Babi Yar instead of "Babii Iar,"and so forth. Bibliographical references, including titles of Russian-language periodicals, in the main text, footnotes, and the bibliography of primary sources are rendered in the standard Library of Congress system of transliterating the Russian alphabet, without diacritical marks.

We have adopted the transliteration system established by YIVO and commonly used in English contexts for the spelling of all Yiddish words and expressions, including those using Cyrillic in the Russian originals. The Yiddish Dictionary Sourcebook: A Transliterated Guide to the Yiddish Language by Herman Galvin and Stan Tamarkin (Hoboken, NJ: Ktav, 1986) has been a useful resource for verifying spellings. Hebrew words and expressions have been transliterated to conform to English-language rather than Russian-language standards.

While the bibliography of primary sources lists transliterated Russian titles of all literary works, the editor's general introduction and the editor's introductions to individual authors and their works provide transliterated Russian titles or transliterated quotations from the Russian originals only where the editor has deemed it absolutely necessary. Otherwise, English translations, as literal as possible, are provided instead.

Where a Russian periodical is mentioned for the first time in a particular entry, the English translation is followed by the Russian title in parentheses. In some cases, however, major Russian periodicals, such as Pravda or Novy mir, are known in English-language scholarship by their original names and have gained common spellings. These titles have not been translated. 
All quotations from the Hebrew Bible are from A New Translation of the Holy Scriptures According to the Traditional Hebrew Text (Philadelphia: The Jewish Publication Society, 1985); all quotations from the New Testament are from The Revised English Bible with Apocrypha (Oxford/Cambridge: Oxford University Press/Cambridge University Press, 1989).

In working on this anthology, the editor drew on a number of published and some unpublished sources. The following encyclopedias and dictionaries proved invaluable: Encyclopedia Judaica, 16 vols. (Jerusalem, 1972); Evreiskaia entsiklopediia, 16 vols. (St. Petersburg, 1906-13); Kratkaia evreiskaia entsiklopediia, 10 vols. plus 3 supplements (Jerusalem, 1976-2001); The New Standard Jewish Encyclopedia, new revised edition (New York, 1992); Russkie pisateli 1900-1917: biograficheskii slovar', 5 vols. pub. to date (Moscow, 1989-).

Unless otherwise specified, the dates in the table of contents and at the end of each individual text refer to the completion of the work; in some instances, the date of first publication follows if it differs significantly from the date of completion. Unless otherwise specified, a parenthetical date in the editor's general introduction, the editor's introductions to the individual authors and their works, or the notes refers to the first publication of a work; in some cases, the date of completion precedes if it differs significantly from the date of first publication. Parenthetical dates for nonliterary works always refer to the date of publication. Where two dates are provided for a historical event, the first refers to the Julian calendar, used in Russia prior to 1918, and the second to the Gregorian calendar.

For information about the primary sources that have been consulted and the history of the publication of all the works included in the anthology, please see the bibliography of primary sources following the Selected Bibliography at the end of this anthology.

Unless otherwise indicated, all translations from the Russian in the introductory essays, headnotes, explanatory notes, and footnotes are by Maxim D. Shrayer.

Unless otherwise indicated, all bibliographical notes, introductory essays and headnotes, explanatory notes, footnotes, and bibliographies are by Maxim D. Shrayer. 